\title{
Impact of COVID-19 pandemic on Black, Asian and Minority Ethnic (BAME) communities: a qualitative study on the perspectives of BAME community leaders
}

Fesani Mahmood ${ }^{1}$, Dev Acharya ${ }^{2}$, Kanta Kumar $^{3}$, Vibhu Paudyal $^{1}$

${ }^{1}$ School of Pharmacy, Institute of Clinical Sciences, University of Birmingham, Edgbaston, B15 2TT

${ }^{2}$ Faculty of Education, Health \& Wellbeing, University of Wolverhampton, Wulfruna Street, West Midlands, WV1 1LY

${ }^{3}$ Institute of Clinical Sciences, College of Medical and Dental Sciences, University of Birmingham, B15 2TT

\section{Corresponding author}

Vibhu Paudyal, $\mathrm{PhD}$

School of Pharmacy, College of Medical and Dental Sciences

University of Birmingham, Edgbaston, Birmingham,

United Kingdom B15 2TT

Tel: 0044-121 4142538

E-mail: v.paudyal@bham.ac.uk

Word count: 3,303

1 Key words: Coronavirus, COVID-19, BAME, minority ethnic, health inequality 


\section{Impact of COVID-19 pandemic on Black, Asian and Minority Ethnic (BAME) communities: a qualitative study on the perspectives of BAME community leaders}

\section{ABSTRACT}

3 Objectives: The aim of this study was to explore the perspectives of BAME community

4 leaders in relation to - the impact of the COVID-19 pandemic on their communities; and

5 BAME community's perception, understanding and adherence to Government guidelines on

6 COVID-19 public health measures.

7 Design: A phenomenological approach was adopted using qualitative semi-structured

8 interviews.

9 Settings: Community organisations and places of worships in the West Midlands region of

10 England.

11 Participants: Community leaders were recruited through organisations representing BAME 12 communities and religious places of worship.

13 Results: A total of 19 participants took part. Participants alluded to historical and structural

14 differences for the observed disparities in COVID-19 morbidity and mortality. Many

15 struggled with lockdown measures which impeded cultural and religious gatherings that were

16 deemed to be integral to the community. Cultural and social practices led to many suffering

17 on their own as discussion of mental health was still deemed a taboo within many

18 communities. Many expressed their community's reluctance to report symptoms for the fear

19 of financial and physical health implications. They reported increase in hate crime which was

20 deemed to be exacerbated due to perceived insensitive messaging from authority officials

21 and historical structural biases. Access and adherence to government guidelines was an

22 issue for many due to language and digital barriers. Reinforcement from trusted community

23 and religious leaders encouraged adherence. Points of support such as food banks were 
medRxiv preprint doi: https://doi.org/10.1101/2021.03.03.21252286; this version posted March 3, 2021. The copyright holder for this preprint (which was not certified by peer review) is the author/funder, who has granted medRxiv a license to display the preprint in perpetuity.

It is made available under a CC-BY-NC-ND 4.0 International license .

24 vital in ensuring essential supplies during the pandemic. Many could not afford masks and

25 sanitisers.

26 Conclusion: The study highlights the perceived impact of COVID-19 pandemic on BAME

27 communities. Government agencies and public health agencies need to integrate with the

28 community, and community leaders to penetrate the key messages and deliver targeted yet

29 sensitive public health advice which incorporates cultural and religious practices. Addressing

30 route cause of disparities is imperative to mitigate current and future pandemics.

31 Key words: Coronavirus, COVID-19, BAME, minority ethnic, health inequality

33 Strengths and limitations of this study

- To our knowledge, this is the first study in England to investigate the understanding of risk and impact of COVID-19 using the perspectives of BAME community leaders.

- Participants represented diverse BAME community organisations and places of worship.

- Participant recruitment was limited to one of the seven regions within England with the highest proportion of BAME populations.

- Results may not be generalizable to any BAME communities not represented in the data. 
medRxiv preprint doi: https://doi.org/10.1101/2021.03.03.21252286; this version posted March 3, 2021. The copyright holder for this preprint

\section{Impact of COVID-19 pandemic on Black, Asian and Minority Ethnic (BAME) communities: a qualitative study on the perspectives of BAME community leaders}

\section{INTRODUCTION}

44 Coronavirus disease (COVID-19) was declared a global pandemic in March 2020, with over 45120,000 deaths from the virus in the UK as of February $2021 .{ }^{1}$ There was early recognition 46 that Black, Asian and Minority Ethnic (BAME) groups in the UK were disproportionately

47 affected, ${ }^{2,3}$ which came to public attention when the first ten doctors who had died from

48 COVID-19 were of BAME origin. ${ }^{4}$ During the first wave in April 2020, approximately $35 \%$ of

49 almost 2,000 intensive care patients for COVID-19 in England, Wales and Northern Ireland

50 were non-White. ${ }^{5}$ However, BAME groups only constitute $13 \%$ of the UK's population. ${ }^{6}$

51 Recent estimates suggest that Chinese, Indian, Pakistani, other Asian, Black Caribbean and

52 other Black ethnicity had between $10-50 \%$ higher mortality risk compared to the White British

53 population. ${ }^{7}$

54 Historically, health inequalities have been a concern for BAME groups; for example, disparity

55 has been observed through higher prevalence of type 2 diabetes and cardiovascular disease

56 in South Asian communities. ${ }^{8}$ The concept is defined as "avoidable and unfair differences"

57 shaped by their surrounding circumstances, namely wider determinants of health. ${ }^{9}$ Factors

58 such as socio-economic status, cultural practices and environmental conditions -which are

59 largely influenced by structural biases based on ethnicity, collectively drive inequalities.

60 Whilst literature reinforces the understanding that BAME groups are disproportionately

61 affected by COVID-19, there is a lack of research that aims to understand the disparity from

62 the perspectives of BAME communities.

63 Urgency of further study into the association between ethnicity and COVID-19 was

64 highlighted in research and policy domains in early 2020. Data from the Office for National

65 Statistics (ONS) proposed that existing co-morbidities in BAME COVID-19 patients could

66 have contributed towards the disparity. ${ }^{10}$ However, the debate later incorporated wider social 
medRxiv preprint doi: https://doi.org/10.1101/2021.03.03.21252286; this version posted March 3, 2021. The copyright holder for this preprint (which was not certified by peer review) is the author/funder, who has granted medRxiv a license to display the preprint in perpetuity.

It is made available under a CC-BY-NC-ND 4.0 International license .

67 and structural disparities. Factors such as deprivation, living conditions, nature of

68 employment were linked to higher morbidity and mortality in BAME populations. ${ }^{11}$

69 In addition to the disparities in morbidity and mortality directly as a result of COVID-19,

70 anecdotal media reports have stated that BAME communities have been under protected,

71 stigmatised during this pandemic. ${ }^{12}$ Currently there is a sparse literature exploring the

72 understanding of BAME groups on how they, themselves, perceive their disparity in COVID-

73 19. To mitigate the pandemic and its impact, diverse information were disseminated through

74 social and broadcast media by the UK Government and public health organisations. Slogans

75 such as 'Stay Home, Protect the NHS, Save Lives' endeavoured to support the first national

76 lockdown in the UK. During this period, non-essential businesses, community organisations

77 and places of worship, which are integral to many BAME communities, were inaccessible..$^{13}$

78 Downloadable translations of key documents, including posters for COVID-19 symptoms

79 were made available in England through Public Health England in eleven different

80 languages ${ }^{14}$ However, BAME communities' understanding of pandemic-related

81 communication from the Government and public health organisations has not yet been

82 investigated.

83 The aim of this study was to explore the perspectives of BAME community leaders in relation

84 to: the impact of the COVID-19 pandemic on their communities; and BAME community's

85 perception, understanding and adherence to Government guidelines on COVID-19 public

86 health measures.

\section{METHODS}

88 Design

89 A phenomenological approach using qualitative study design was adopted. ${ }^{15}$

\section{Study population, sampling strategy and recruitment}


medRxiv preprint doi: https://doi.org/10.1101/2021.03.03.21252286; this version posted March 3, 2021. The copyright holder for this preprint (which was not certified by peer review) is the author/funder, who has granted medRxiv a license to display the preprint in perpetuity.

It is made available under a CC-BY-NC-ND 4.0 International license .

91 Leader or representatives of the organisations, businesses and places of worship serving a

92 predominantly BAME community in the West Midlands region of England, a region that

93 suffered most BAME related hospital admissions and mortality, were searched online, then

94 invited via email or telephone. Organisations were identified through internet, social media

95 search and acquaintance of the research team (all representing BAME communities). Those

96 expressing interest were emailed a Participant Information Sheet and Consent Form.

97 Additional recruitment was made through snowball sampling. The ethnic groups of interest

98 (Electronic supplementary material 1 ) were of those recommended by the UK Government. ${ }^{16}$

\section{Ethical approval and consent}

100 Ethical approval was obtained from the University of Birmingham School of Pharmacy Ethics

101 Committee (reference number UoB/SoP/2020-64). Informed consent was received from all

102 participants.

\section{Data collection material and methods}

104 An interview topic guide (Electronic supplementary material 2) was developed with 19 openended questions on three key areas regarding BAME community's: (1) understanding of acquiring COVID-19 risk and disparity in health outcomes; (2) beliefs and perspectives relating to COVID-19; and (3) understanding and adherence to Government-issued guidance and public health measures on COVID-19. Probes elicited a comprehensive insight from participants. To test face and content validity, the research team developed questions based on existing literature and a pilot interview was conducted with a BAME community member which ensured clarity of the questions. No changes had to be made to the topic guide.

112 Participants were recruited and interviewed between October - November 2020 for

113 approximately 45 minutes over Zoom or telephone. Relevant demographic information was

114 collected prior to the interview. Interviews were audio-recorded using the recording function

115 on Zoom or a digital voice recorder, respectively. 
medRxiv preprint doi: https://doi.org/10.1101/2021.03.03.21252286; this version posted March 3, 2021. The copyright holder for this preprint (which was not certified by peer review) is the author/funder, who has granted medRxiv a license to display the preprint in perpetuity.

It is made available under a CC-BY-NC-ND 4.0 International license .

\section{Data processing and analysis}

118 Recordings were transcribed verbatim into Microsoft Word. Data was anonymised to remove

119 any identifiable information. Transcripts were exported onto Microsoft Excel and then

120 thematically analysed by two researchers (FM and VP) using framework technique. ${ }^{17-19}$ The

121 initial coding was reviewed between the research team through analysis of first two

122 transcripts before an agreed version that could be applied to the rest of the transcripts. New

123 themes were as they emerged during the subsequent analysis of other transcripts.

124 Reporting was conducted to comply with the COREQ guideline ${ }^{20}$ and checklist (electronic

125 supplement material 3).

\section{Patient and public involvement}

127 Apart from members of public's participation in the research as study subjects, no other PPI

128 activities were conducted for this research due to time and resource constraints.

\section{RESULTS}

130 A total of 19 participants from various community leadership roles and BAME

131 representations took part (table 1). Four overarching themes and 11 subthemes were

132 identified (tables 2-5). Themes related to a) perceived impact of COVID-19 and lockdown on

133 wellbeing $b$ ) understanding of risk and disparity in health outcomes for COVID-19; c)

134 perception, understanding and adherence to Government guidance in relation to COVID-19;

135 d) accessibility and use of community services, and other points of support, during the

136 pandemic. Narrative summaries of each theme are presented below and illustrative quotes

137 are presented in tables 2, 3, 4 and 5 dedicated to each theme.

138 Table 1 placeholder

139

140 A) Perceived impact of COVID-19 and lockdown on wellbeing 
medRxiv preprint doi: https://doi.org/10.1101/2021.03.03.21252286; this version posted March 3, 2021. The copyright holder for this preprint (which was not certified by peer review) is the author/funder, who has granted medRxiv a license to display the preprint in perpetuity.

It is made available under a CC-BY-NC-ND 4.0 International license .

\section{Mental health impact and psychological wellbeing}

142 This was widely expressed by all participants, with feelings of anxiety being exacerbated by

143 social isolation appearing to culminate in emotional fatigue, owing to the longevity of the

144 pandemic. Participants alluded to the close knit nature of the BAME communities and the

145 pandemic and the lockdown had an immense impact on their social wellbeing. Some also

146 reported that women within families may have suffered a notable impact due to additional

147 strain from domestic responsibilities during lockdown (table 2).

148 Whilst participants differed in their perspectives on whether adequate mental health support

149 was available during and after the first national lockdown, all recognised that further

150 education within their respective communities was required to break the taboo that

151 presented a barrier to expressing emotion, and encourage those who require support to

152 actively seek it. Participants of Asian and Black African communities described that mental

153 health was still deemed a taboo within the communities and many had to suffer in isolation

154 (table 2).

\section{Financial impact}

156 The subsequent financial impact from the national lockdown was an overriding concern for

157 BAME communities, particularly for those on lower incomes and in self-employment.

158 Financial insecurity as a result of the pandemic was especially difficult for families, as

159 several participants mentioned that many in their communities were reliant on Government

160 welfare (table 2).

161 Physical health impact

162 Current and future physical health was a concern expressed by many participants (table 2).

163 They recognised that their communities are often predisposed to certain chronic conditions

164 which may result in worse outcomes, due to the current treatment prioritisation of COVID-19.

165 Examples described related to the impact on the ongoing treatment of patients with sickle

166 cell anaemia, thalassemia and prostate cancer that were deemed to be highly prevalent 
medRxiv preprint doi: https://doi.org/10.1101/2021.03.03.21252286; this version posted March 3, 2021. The copyright holder for this preprint (which was not certified by peer review) is the author/funder, who has granted medRxiv a license to display the preprint in perpetuity.

It is made available under a CC-BY-NC-ND 4.0 International license .

167 amongst Black African communities. Therefore, those with underlying conditions were taking

168 extra precautions to maintain optimum health, should they be affected by COVID-19.

169 Leaders mentioned their community's fear of being admitted to hospital due to the worry of

170 potentially dying away from loved ones. Mistrust in the health services appeared to be

171 propagated by social media and prior negative experiences in healthcare; this stopped many

172 from self-reporting if they had symptoms (table 2).

\section{Social impact}

174 Some participants reported an increase in targeted online hate crime, perhaps due to media 175 representation of their community during this pandemic (table 2). The high prevalence of

176 COVID-19 in BAME communities and the media representations have resurfaced historic

177 structural biases against their community, with some commenting strongly on the perceived

178 discrimination. Similarly, leaders noted the perceived lack of support for their respective

179 BAME groups regarding COVID-19 and its effects.

180 Participants also described the taboo within their own communities meant many were

181 suffering in isolation. Many would also be unwilling to report symptoms if it meant that they

182 would have to self-isolate, due to consequent financial loss and, sometimes, stigmatisation

183 from fellow community members (table 2).

184 Leaders expressed their communities' struggles with restrictions on social distancing and

185 lockdown measures that had greatly impacted on what would otherwise be high-volume

186 cultural and religious gatherings, from festivities to funerals (table 2).

187 Table 2 placeholder

188 B) Understanding of risk and disparity in health outcomes for COVID-19

189 Acceptance, scepticism and ignorance

190 Participants spoke of varying degrees of acceptance, with most describing their communities

191 accepting their increased risk of transmission, infection and worse health outcomes 
medRxiv preprint doi: https://doi.org/10.1101/2021.03.03.21252286; this version posted March 3, 2021. The copyright holder for this preprint (which was not certified by peer review) is the author/funder, who has granted medRxiv a license to display the preprint in perpetuity.

It is made available under a CC-BY-NC-ND 4.0 International license .

192 compared to the White British population. However, scepticism of the virus's impact was

193 expressed by the participants, particularly due to the disproportionate death toll in the UK

194 compared to their native country (table 3). All mentioned that the greatest health impact was

195 on those who were elderly and vulnerable within their community, including those with

196 underlying health conditions and disabilities (table 3).

197 Perceptions around ethnic, cultural, societal and environmental contexts as risk

198 factors

199 Neighbourhood deprivation was commonly described, with many commenting on poor

200 lifestyles and socioeconomic status fuelling the disparity (table 3). This was linked to

201 education level and employment nature, especially for those in the service sector with high

202 public exposure. Participants discussed multigenerational living contributing towards the high

203 prevalence. For younger generations who were conscious of the risk, it was reported that

204 some may have struggled to communicate this to elders within their family and wider

205 community due to cultural hierarchies (table 3).

206 Table 3 placeholder

207 C) Perception, understanding and adherence to Government guidance in relation to

208 COVID-19

209 Understanding and clarity

210 Almost all participants stated that Government guidance was inconsistent and lacked clarity.

211 The subsequent effect was worsened for community members who were not fluent in

212 English, with translated guidance lacking in forms that could be accessed and understood by

213 all. This, combined with the community's close-knit nature, was reported to have perhaps

214 influenced their interpretation of social distancing guidelines between households (table 4).

215 Poor outreach 
medRxiv preprint doi: https://doi.org/10.1101/2021.03.03.21252286; this version posted March 3, 2021. The copyright holder for this preprint (which was not certified by peer review) is the author/funder, who has granted medRxiv a license to display the preprint in perpetuity.

It is made available under a CC-BY-NC-ND 4.0 International license .

216 Digital exclusivity exacerbated weak understanding, with leaders mentioning that the

217 pandemic revealed the lack of digital access for their most deprived (table 4). Participants

218 described how they took on the role of disseminating Government guidance; a common

219 sentiment was that of wonder to how else their community would have received such

220 information without their input. Some mentioned that media representation and comments by

221 Government officials made their community feel marginalised, as it sometimes appeared to

222 be targeted directly towards particular ethnic groups (table 4).

\section{Adherence, or lack of, to Government guidance}

224 Participants deemed that communities in more deprived areas appearing to have weaker

225 uptake of guidelines. Other risk avoidance behaviours included the use of home remedies,

226 which were perceived to have great benefit and were linked to cultural and religious

227 practices (table 4).

228 Facilitators affecting adherence including personal value, such as being able to resume

229 congregational worship. Reinforcement from local authority and trusted community and

230 religious leaders encouraged adherence. In contrast, the simplicity of some guidelines

231 (wearing face masks and avoiding non-essential travel) appeared to make some question

232 the necessity of abiding by them, especially when Government officials were also seen to

233 publicly break the rules without consequence (table 4).

234 Table 4 placeholder

235 D) Accessibility and use of community services, and other points of support, during

236 the pandemic

237 Accessibility and lack of resources

238 Some mentioned their community had restricted or no access to culturally-appropriate

239 service providers and places of worship that they would normally frequent. Many commented 
medRxiv preprint doi: https://doi.org/10.1101/2021.03.03.21252286; this version posted March 3, 2021. The copyright holder for this preprint (which was not certified by peer review) is the author/funder, who has granted medRxiv a license to display the preprint in perpetuity.

It is made available under a CC-BY-NC-ND 4.0 International license .

240 on inadequate access to General Practitioners, a healthcare professional their community

241 holds in high regard and would usually turn to (table 5).

\section{Points of support}

243 All commented on their community's feeling of servitude towards each other during the

244 pandemic (table 5). Family and friends were reported to be the immediate support network.

245 As lockdown restrictions eased, community centres and places of worship were stated to

246 have responded to their local's needs by launching services, such as food banks and

247 befriending projects, which were not previously required (table 5).

248 Table 5 placeholder

\section{DISCUSSION}

250 The aim of this study was to investigate the impact of COVID-19 pandemic on BAME

251 communities. The findings reveal the inequalities as experienced by leaders of diverse

252 BAME communities. Participants alluded to the disparities in infection rates and outcomes to

253 historical and structural differences. Many community members experienced racism and

254 stigmatisation during the pandemic. Cultural and social practices within the communities led

255 to many suffering on their own as discussion of mental health was still deemed a taboo

256 within many BAME communities.

257 Participants identified their community members faced barriers to adherence to government

258 guidelines. Lack of English proficiency particularly contributed to this. Despite translated

259 documents, there was often an issue of illiteracy in the native language for some community

260 members, with a number of participants mentioning the need for interpreters to verbally

261 deliver guidance. It is known that deliverance of Government guidelines was markedly

262 affected by digital exclusion. In 2019 , only $10.6 \%$ of White ethnic groups in the West

263 Midlands were found to be "internet non-users", whilst the collective percentage for all other

264 ethnic groups (as included in our study) was reported at $39.9 \% .{ }^{21}$ In addition, some

265 participants described that lack of access to sanitizers and masks during the early phase of 
medRxiv preprint doi: https://doi.org/10.1101/2021.03.03.21252286; this version posted March 3, 2021. The copyright holder for this preprint (which was not certified by peer review) is the author/funder, who has granted medRxiv a license to display the preprint in perpetuity.

It is made available under a CC-BY-NC-ND 4.0 International license .

266 the pandemic led to further difficulties in adherence for the most disadvantaged in their

267 community.

268 Stigmatisation of mental health has frequently been documented within BAME communities;

269 this perceived barrier to seeking support from peers or professionals were described by our

270 study participants. Our findings also revealed a mental health impact from the lockdown

271 particularly on women with familial responsibilities in BAME communities. This also

272 extended to the lack of adequate bereavement support. Many communities could not grieve

273 as usual due to lockdown restrictions. For instance, the Muslim community initially could not

274 perform burial rites within 24 hours, an otherwise-expected practice. This was quickly

275 ameliorated by emergency Government legislation which respected the community's

276 wishes. ${ }^{22}$ Such practice from authority level should be implemented for other minority ethnic

277 groups regarding the particular challenges their communities face during this pandemic.

278 Participants described overcrowding due to multi-generational living as a risk factor for the

279 observed disparities and contributor to weak adherence of social distancing guidelines.

280 Many alluded to poor housing conditions. The ONS have reported that only $2 \%$ of White

281 British households are overcrowded, compared to $10 \%$ for other ethnic groups. ${ }^{23}$ Participants

282 also commented on the nature of employment their community members typically hold,

283 including key worker roles during the pandemic (such as transport operatives and hospital

284 porters) overexposed them to the virus. ${ }^{24}$ High prevalence of such employment amongst

285 BAME communities have been linked to poorer education levels associated with historic

286 structural biases and systemic inequality. ${ }^{24}$ This is reiterated by research stating that such

287 factors interplay with ethnicity, resulting in poor health for minority ethnic groups. ${ }^{25}$

\section{Strength and limitations}

289 To our knowledge, this was the first study to investigate the understanding of risk and impact

290 of COVID-19 using the perspectives of BAME community leaders in England. An extensive

291 variety of community leaders were recruited through an intensive search of BAME 
medRxiv preprint doi: https://doi.org/10.1101/2021.03.03.21252286; this version posted March 3, 2021. The copyright holder for this preprint (which was not certified by peer review) is the author/funder, who has granted medRxiv a license to display the preprint in perpetuity.

It is made available under a CC-BY-NC-ND 4.0 International license .

292 community organisations, businesses and places of worship. Thus, key informants could

293 share the experiences of COVID-19 pandemic on their BAME community through the study's

294 qualitative design. The interviewing-researcher's own BAME origin may have also allowed

295 participants to openly discuss sensitive issues, thus eliciting detailed perspectives.

296 Duplicate analysis of interviews provided rigour, and data saturation was assumed after 19

297 participants since no new themes had emerged. However, these findings are not

298 representative of all BAME groups. For example, we could not recruit anyone from East

299 Asian communities. Leaders not of BAME origin themselves but who could speak on behalf

300 on BAME communities (such as councillors of White ethnicity representing a West Midlands

301 constituency with a high ethnic demographic) were approached, but we did not receive

302 response from anyone available to participate. Moreover, our methodology's use of

303 Government-standardised ethnic grouping was very broad, but our results indicated that the

304 experiences of this pandemic varied hugely across different ethnicities that would be classed

305 together. For instance, the Somali diaspora in inner-city Birmingham had very different

306 understanding and experiences of COVID-19 compared to the Caribbean community in

307 outskirt boroughs.

308 Although not an aim of this study, there is weakness in its lack of generalisability as it was

309 limited to a geographical region within England. However, this region represents the second

310 highest proportion of BAME populations within England. ${ }^{26}$

\section{Implications for practice and research}

312 Further work needs to be urgently undertaken during this ongoing pandemic to improve

313 adherence to the Government guidelines within BAME communities and mitigate the

314 disproportionate impact of COVID-19. This includes increasing outreach and providing

315 logistical and financial support at a grassroots level to the most vulnerable in already-

316 marginalised communities. Public health guidance must be produced in different languages

317 and dialects through accessible media, not only on how to stay safe from COVID-19 but to 
medRxiv preprint doi: https://doi.org/10.1101/2021.03.03.21252286; this version posted March 3, 2021. The copyright holder for this preprint (which was not certified by peer review) is the author/funder, who has granted medRxiv a license to display the preprint in perpetuity.

It is made available under a CC-BY-NC-ND 4.0 International license .

318 also challenge myths propagated by social media. Public health campaigns should

319 incorporate nuances that BAME communities can resonate with, such as the perceived

320 benefit of home remedies, to deliver targeted but culturally sensitive interventions. All

321 aforementioned recommendations should be implemented with cooperation between health

322 services and trusted community networks, religious leaders and local stakeholders. This

323 approach would be beneficial in other global or national public health interventions and any

324 future pandemics, should they occur.

325 Future research could investigate which intra-demographic characteristics within a certain

326 BAME community affect their perceptions and impact of COVID-19, and to what extent. This

327 includes factors identified by this study, such as cultural hierarchies. The collective

328 addressing of all non-White demographics into one overarching BAME category should also

329 be questioned and adapted, as this study has demonstrated that one solution will not

330 encompass the needs of all BAME communities. Perspectives of other population groups

331 who are likely to face multiple social disadvantage during the time of pandemic such as the

332 homeless populations, ${ }^{27-29}$ refugees $^{30}$ and single people living ${ }^{31}$ needs to be researched.

333 CONCLUSION

334 BAME community leader participants of this study alluded to historical and structural

335 differences for the observed disparities in COVID-19 morbidity and mortality. In addition,

336 cultural and social practices within the communities led to many suffering on their own as

337 discussion of mental health was still deemed a taboo within many communities. Racial

338 discriminations added to their worries during the pandemic. Reinforcement from trusted

339 community and religious leaders encouraged adherence to government guidelines. Points of

340 support such as food banks were vital in ensuring essential supplies during the pandemic.

341 Government agencies and public health bodies need to integrate with the community, and

342 community leaders to penetrate the key messages and deliver targeted yet sensitive public

343 health advice which incorporates cultural and religious practices. Addressing route cause of

344 disparities is imperative to mitigate current and future pandemics. These must be addressed 
medRxiv preprint doi: https://doi.org/10.1101/2021.03.03.21252286; this version posted March 3, 2021. The copyright holder for this preprint (which was not certified by peer review) is the author/funder, who has granted medRxiv a license to display the preprint in perpetuity.

It is made available under a CC-BY-NC-ND 4.0 International license .

345 by using appropriate and targeted public health interventions. Such interventions should be

346 emboldened by the governmental sphere foremost, then perpetuated by local authority in

347 collaboration with community leaders. Ultimately, all strategies must be guided by BAME

348 communities themselves in order to successfully meet their needs.

\section{Acknowledgments}

350 We are grateful to every participant for their time and support in this study, without whom this 351 research could not have been conducted.

\section{Conflict of interest statement}

353 None declared.

\section{Funding}

355 This research did not receive any specific grant from funding agencies in the public,

356 commercial, or not-for-profit sectors.

\section{Author contributions}

358 FM, VP and DA co-designed the study. FM conducted all interviews and transcribed the data. FM and VP conducted the analysis in duplicate to which DA and KK added their input through expert comments. FM led the write up of the manuscript to which all authors contributed through editing and expert comments. All authors agree to the final version of the manuscript.

\section{Competing interests}

364 Apart from authors themselves representing diverse BAME backgrounds, there are no other conflict of interests to declare.

\section{Checklist}

367 This work follows COREQ recommendations and is reported as per the COREQ checklist.

368 (Electronic Supplement 3) 
medRxiv preprint doi: https://doi.org/10.1101/2021.03.03.21252286; this version posted March 3, 2021. The copyright holder for this preprint (which was not certified by peer review) is the author/funder, who has granted medRxiv a license to display the preprint in perpetuity.

It is made available under a CC-BY-NC-ND 4.0 International license .

\section{Data availability}

370 All relevant data pertaining to this manuscript are presented in the manuscript and the

371 electronic supplementary materials.

\section{REFERENCES}

373 1) John Hopkins University Coronavirus Resource Centre. Mortality analysis. Available at

374 https://coronavirus.jhu.edu/data/mortality . Last accessed 22 February 2021.

375 2) The Guardian. Ethnic minorities dying of Covid-19 at higher rate, analysis shows (22 April 2020).

376 Available at: https://www.theguardian.com/world/2020/apr/22/racial-inequality-in-britain-found-a-

377 risk-factor-for-covid-19. Last accessed 22 February 2021.

378 3) GOV.UK Deaths in United Kingdom (2021). Available at:

379 https://coronavirus.data.gov.uk/details/deaths (8 January 2021, date last accessed).

380 4) The Guardian. 'So much living to do': stories of UK's coronavirus victims (2020). Available at:

$381 \mathrm{https}: / / \mathrm{www}$.theguardian.com/world/2020/mar/18/not-ready-to-go-tributes-paid-to-uk-first-named-

382 victims-of-coronavirus (8 January 2021, date last accessed).

383 5) Intensive Care National Audit \& Research Centre. ICNARC report on COVID-19 in critical care

384 (2020). Available at: https://www.icnarc.org/DataServices/Attachments/Download/c31dd38d-

385 d77b-ea11-9124-00505601089b (8 January 2021, date last accessed).

386 6) Office for National Statistics. 2011 Census: Key Statistics and Quick Statistics for Local

387 Authorities in the United Kingdom (2013). Available at:

$388 \mathrm{https}: / / \mathrm{www} .0 n s . g o v . u k / p e o p l e p o p u l a t i o n a n d c o m m u n i t y /$ populationandmigration/populationestima

389 tes/bulletins/keystatisticsandquickstatisticsforlocalauthoritiesintheunitedkingdom/2013-10-11 (8

390 January 2021, date last accessed).

391 7) Public Health England. Disparities in the risk and outcomes of COVID-19 (2020). Available at:

$392 \mathrm{https}: / /$ assets.publishing.service.gov.uk/government/uploads/system/uploads/attachment_data/file

393 /908434/Disparities_in_the_risk_and_outcomes_of_COVID_August_2020_update.pdf (8 January

3942021 , date last accessed).

395 8) Nishino Y, Gilmour S, Shibuya K. Inequality in diabetes-related hospital admissions in England by

396 socioeconomic deprivation and ethnicity: facility-based cross-sectional analysis. PloS one.

$397 \quad 2015 ; 10(2): e 0116689$. 
medRxiv preprint doi: https://doi.org/10.1101/2021.03.03.21252286; this version posted March 3, 2021. The copyright holder for this preprint (which was not certified by peer review) is the author/funder, who has granted medRxiv a license to display the preprint in perpetuity.

It is made available under a CC-BY-NC-ND 4.0 International license .

398

399

400

401

402

403

404

405

406

407

408

409

410

411

412

413

414

415

416

417

418

419

420

421

422

423

424

425

426

9) McCartney G, Popham F, McMaster R, Cumbers A. Defining health and health inequalities. Public Health (2019) 172: 22-30. doi: 10.1016/j.puhe.2019.03.023

10) Office for National Statistics. Updating ethnic contrasts in deaths involving the coronavirus (COVID-19), England and Wales: deaths occurring 2 March to 28 July 2020 (2020). Available at: https://www.ons.gov.uk/peoplepopulationandcommunity/birthsdeathsandmarriages/deaths/articles /updatingethniccontrastsindeathsinvolvingthecoronaviruscovid19englandandwales/deathsoccurrin g2marchto28july2020 (8 January 2021, date last accessed).

11) Pareek M, Bangash MN, Pareek N, Pan D, Sze S, Minhas JS. Ethnicity and COVID-19: an urgent public health research priority. Lancet (2020) 395: 10234. doi: 10.1016/S0140-6736(20)30922-3

12) The Guardian. Structural racism led to worse COVID impact on BAME groups. Available at: https://www.theguardian.com/world/2020/oct/27/structural-racism-led-to-worse-covid-impact-onbame-groups-report (22 February 2021, date last accessed).

13) GOV.UK. Coronavirus: stay at home, protect the NHS, save lives - web version (2020). Available at: https://www.gov.uk/government/publications/coronavirus-covid-19-informationleaflet/coronavirus-stay-at-home-protect-the-nhs-save-lives-web-version (8 January 2021, date last accessed).

14) Public Health England. Coronavirus resources - translations (2020). Available at: https://coronavirusresources.phe.gov.uk/the-nhs-covid-19-app/resources/Translations-Posters/ (8 January 2021, date last accessed).

15) Green J, Thorogood N. Qualitative Methods for Health Research. London: SAGE Publications (2018). 387 p.

16) GOV.UK. List of ethnic groups (no date). Available at: https://www.ethnicity-factsfigures.service.gov.uk/style-guide/ethnic-groups [Accessed January 8, 2021].

17) Braun V, Clarke V. Using thematic analysis in psychology. Qual Res Psychol (2008) 3:2. doi: $10.1191 / 1478088706 q p 0630 a$

18) Burnard $P$, Gill $P$, Stewart $K$, Treasure $E$, Chadwick $B$. Analysing and presenting qualitative data. Br Dent J (2008) 204:8. doi: 10.1038/sj.bdj.2008.292.

19) Ritchie J, Spencer L. Qualitative data analysis for applied policy research. The qualitative researcher's companion. 2002;573:305-329. 
medRxiv preprint doi: https://doi.org/10.1101/2021.03.03.21252286; this version posted March 3, 2021. The copyright holder for this preprint (which was not certified by peer review) is the author/funder, who has granted medRxiv a license to display the preprint in perpetuity.

It is made available under a CC-BY-NC-ND 4.0 International license .

427 20) Equator Network. Consolidated criteria for reporting qualitative research (COREQ): a 32-item

428 checklist for interviews and focus groups. https://www.equator-network.org/reporting-

429 guidelines/coreq/ Accessed 23 February 2021.

430 21) Office for National Statistics. Exploring the UK's digital divide (2019). Available at:

431 https://www.ons.gov.uk/peoplepopulationandcommunity/householdcharacteristics/homeinternetan dsocialmediausage/articles/exploringtheuksdigitaldivide/2019-03-04\#how-does-internet-usagevary-for-different-ethnic-groups (8 January 2021, date last accessed).

22) The Muslim Council of Britain. Together in tribulation: British Muslims and the COVID-19 pandemic (2020). Available at: https://mcb.org.uk/wp-content/uploads/2020/11/MCB-Together-inTribulation-British-Muslims-and-the-COVID-19-Pandemic.pdf (8 January 2021, date last accessed).

23) GOV.UK. Overcrowded households (2020) Available at: https://www.ethnicity-factsfigures.service.gov.uk/housing/housing-conditions/overcrowded-households/latest\#by-ethnicityand-area (8 January 2021, date last accessed).

24) Public Health England. Beyond the data: Understanding the impact of COVID-19 on BAME groups (2020). Available at: https://assets.publishing.service.gov.uk/government/uploads/system/uploads/attachment_data/file

26) GOV.UK. Regional ethnic diversity. Available at https://www.ethnicity-factsfigures.service.gov.uk/uk-population-by-ethnicity/national-and-regional-populations/regionalethnic-diversity/latest. Accessed 23 February 2021.

454 27) Perri M, Dosani N, Hwang SW. COVID-19 and people experiencing homelessness: challenges and mitigation strategies. CMAJ. 2020 Jun 29;192(26):E716-9. 
medRxiv preprint doi: https://doi.org/10.1101/2021.03.03.21252286; this version posted March 3, 2021. The copyright holder for this preprint (which was not certified by peer review) is the author/funder, who has granted medRxiv a license to display the preprint in perpetuity. It is made available under a CC-BY-NC-ND 4.0 International license .

456 28) Gunner E, Chandan SK, Marwick S, Saunders K, Burwood S, Yahyouche A, Paudyal V. Provision 457 and accessibility of primary healthcare services for people who are homeless: a qualitative study 458 of patient perspectives in the UK. British Journal of General Practice. 2019 Aug 1;69(685):e52636.

460 29) Paudyal V, Saunders K. Homeless reduction act in England: impact on health services. The $461 \quad$ Lancet. 2018 Jul 21;392(10143):195-7.

462 30) Orcutt M, Patel P, Burns R, Hiam L, Aldridge R, Devakumar D, Kumar B, Spiegel P, Abubakar I. 463 Global call to action for inclusion of migrants and refugees in the COVID-19 response. The $464 \quad$ Lancet. 2020; 395(10235):1482-3.

465 31) Kowal M, Coll-Martín T, Ikizer G, Rasmussen J, Eichel K, Studzińska A, Koszałkowska K, 466 Karwowski M, Najmussaqib A, Pankowski D, Lieberoth A. Who is the most stressed during the 467 covid-19 pandemic? Data from 26 countries and areas. Applied Psychology: Health and 468 Well-Being. 2020;12(4):946-66.

469 
medRxiv preprint doi: https://doi.org/10.1101/2021.03.03.21252286; this version posted March 3, 2021. The copyright holder for this preprint (which was not certified by peer review) is the author/funder, who has granted medRxiv a license to display the preprint in perpetuity.

\author{
It is made available under a CC-BY-NC-ND 4.0 International license .
}

Table 1: Demographics of recruited study participants

\begin{tabular}{|l|l|l|}
\cline { 2 - 3 } \multicolumn{1}{l|}{} & \multicolumn{1}{|c|}{ Participant community role } & \multicolumn{1}{c|}{ Broad ethnic group of community } \\
\hline P1 & Community service provider & Asian/British Asian \\
\hline P2 & School teacher & Asian/British Asian \\
\hline P3 & Pharmacist & Asian/British Asian \\
\hline P4 & Church staff & Black/African/Caribbean/British Black \\
\hline P5 & Mosque imam & Asian/British Asian \\
\hline P6 & Radio presenter & Black African/British Black African \\
\hline P7 & Community service provider & Asian/British Asian \\
\hline P8 & Community service provider & Asian/British Asian \\
\hline P9 & Supermarket manager & Asian/British Asian \\
\hline P10 & Mosque imam & Various BAME groups \\
\hline P11 & Church leader & Black/African/Caribbean/British Black \\
\hline P12 & Community service provider & Yemeni/British Yemeni \\
\hline P13 & Temple manager & Asian/British Asian \\
\hline P14 & Community service provider & Various BAME groups \\
\hline P15 & Church staff & Black/African/Caribbean/British Black \\
\hline P16 & Community service provider staff & Black/African/Caribbean/British Black \\
\hline P17 & School teacher & Asian/British Asian \\
\hline P18 & Community service provider & Black/African/Caribbean/British Black \\
\hline P19 & Community service provider & Black/African/Caribbean/British Black/White and Black \\
& & Caribbean/White and Black African \\
\hline
\end{tabular}


medRxiv preprint doi: https://doi.org/10.1101/2021.03.03.21252286; this version posted March 3, 2021. The copyright holder for this preprint

(which was not certified by peer review) is the author/funder, who has granted medRxiv a license to display the preprint in perpetuity.

It is made available under a CC-BY-NC-ND 4.0 International license .

\section{Table 2 Perceived impact of COVID-19 and lockdown on wellbeing}

\begin{tabular}{|c|c|c|}
\hline $\begin{array}{l}\text { Thematic } \\
\text { subtheme }\end{array}$ & $\begin{array}{c}\text { Thematic } \\
\text { code }\end{array}$ & Illustrative quotes \\
\hline \multirow{4}{*}{$\begin{array}{l}\text { Mental } \\
\text { health } \\
\text { impact and } \\
\text { psychologica } \\
\text { I wellbeing }\end{array}$} & Isolation & $\begin{array}{l}\text { "in the Asian community... from going to mixing with lots of family then all of a } \\
\text { sudden you might not, that's very hard for people" } \\
-\quad \text { P17, Asian/British Asian, school teacher }\end{array}$ \\
\hline & $\begin{array}{l}\text { Emotions and } \\
\text { emotional } \\
\text { fatigue }\end{array}$ & $\begin{array}{l}\text { "the younger ladies... struggled as well..., the kids were at home and they } \\
\text { were saying they're driving them insane, having to do the home-schooling... all } \\
\text { the cooking, cleaning... school gives that break... They found it initially... very } \\
\text { enjoyable being with the family but with a longer period of time it does get a bit } \\
\text { repetitive, kids become ratty, they become...very frustrated... I remember one } \\
\text { parent saying to me... she found it really exhausting." } \\
\text { - P7, Asian/British Asian, community service provider }\end{array}$ \\
\hline & Taboo & $\begin{array}{l}\text { "mental health has a very big stigma in my people..., they don't talk about } \\
\text { mental health, it's a cultural thing. Mental health, they'll tell you, oh my God, } \\
\text { audhu billahi minashaitan [I seek refuge in God from the outcast Satan], ... } \\
\text { what you're talking about, you don't believe in Allah [God]? ... why are you } \\
\text { saying you have a mental health? People will stamp on you... if you say l'm } \\
\text { depressed, you can't ever say that word. It doesn't actually... exist in my } \\
\text { language, believe me, l've tried to... translate it..., it's not there..., it's that bad" } \\
\quad \text { - P6, Black African/British Black African, radio presenter }\end{array}$ \\
\hline & $\begin{array}{l}\text { Education on } \\
\text { mental health } \\
\text { awareness } \\
\text { and support }\end{array}$ & $\begin{array}{l}\text { "mental health isn't really highly regarded in our community... so, we're trying } \\
\text { to do workshops... to kind of bring awareness of it" } \\
\text { - P7, Asian/British Asian, community service provider }\end{array}$ \\
\hline \multirow[t]{2}{*}{$\begin{array}{l}\text { Financial } \\
\text { impact }\end{array}$} & Financial strain & $\begin{array}{l}\text { "during coronavirus, ... people are... struggling because... the things gone up. } \\
\text { Prices gone high, and their earning gone down. Some people are struggling } \\
\text { paying rent..., struggling in their jobs. For example, taxi drivers." } \\
\text { - P5, Asian/British Asian, mosque imam }\end{array}$ \\
\hline & $\begin{array}{l}\text { Recourse to } \\
\text { public funds }\end{array}$ & $\begin{array}{l}\text { "What the Government did which... has impacted... people of African } \\
\text { Caribbean origin, is that... they had a furlough scheme... which they told } \\
\text { everyone... would end in October... Then at the very last minute... announced } \\
\text { that they're gonna [going to]... put the furlough scheme back. But the effect } \\
\text { was, by that time,... there was a lot of unnecessary redundancies... Black } \\
\text { young people are twice... as likely to be unemployed than their White } \\
\text { counterparts. So, they would have been affected by those sort of decisions" } \\
\text { - P16, Black/African/Caribbean/British Black, community service } \\
\text { provider }\end{array}$ \\
\hline \multirow[t]{2}{*}{$\begin{array}{l}\text { Physical } \\
\text { health } \\
\text { impact }\end{array}$} & $\begin{array}{l}\text { Fear of } \\
\text { compromised } \\
\text { safety in } \\
\text { seeking } \\
\text { medical help }\end{array}$ & $\begin{array}{l}\text { "I know people who won't go outside right now because they're afraid of } \\
\text { catching the virus because... if you're BME, you're more likely to [die] ... They } \\
\text { don't wanna [want to] go to the doctors... Some say they're not going to } \\
\text { hospital because, again, they were dying in hospital. They left home... not that } \\
\text { sick, and by the time they get there, they die... So they're fearful of going to } \\
\text { hospital... It's across... the community" } \\
\text { - P11, Black/African/Caribbean/British Black, church leader }\end{array}$ \\
\hline & $\begin{array}{l}\text { Implications of } \\
\text { lockdown on } \\
\text { current and } \\
\text { future health }\end{array}$ & $\begin{array}{l}\text { "Within the African Caribbean community, one of the conditions... is sickle cell } \\
\text { anaemia and thalassemia... Because of the lockdown,... they've been } \\
\text { restricted in terms of the treatment that they can get... Men and prostate } \\
\text { cancer,... it's very high in the African... community. If you're not able to get a } \\
\text { check-up,... that delay can be fatal, because in African Caribbean men, ... } \\
\text { prostate cancer tends to be... a stronger strain... So now,... there's a potential } \\
\text { that people out there have either passed away or moved into stage four when, } \\
\text { if services had been available, they wouldn't have... So... there will be... some } \\
\text { deaths that are unnecessary, really, because of this lockdown" } \\
\text { - P16, Black/African/Caribbean/British Black, community service } \\
\text { provider }\end{array}$ \\
\hline $\begin{array}{l}\text { Social } \\
\text { impact }\end{array}$ & $\begin{array}{l}\text { Restricted } \\
\text { cultural and } \\
\text { religious } \\
\text { gatherings }\end{array}$ & $\begin{array}{l}\text { "When somebody dies in the community, we get hundreds of people, it's not } \\
\text { about } 15 \text { or } 30, \text { it's hundreds... I think a lot of our cultural norms,... it's like it's } \\
\text { been eradicated, or just taken away... To all of a sudden restrict the amount of } \\
\text { people who can attend church, and then when you're there, ... we can't } \\
\text { worship like... we used to, because we're quite vocal, we're very expressive } \\
\text { and all that's been... taken away" }\end{array}$ \\
\hline
\end{tabular}


medRxiv preprint doi: https://doi.org/10.1101/2021.03.03.21252286; this version posted March 3, 2021. The copyright holder for this preprint (which was not certified by peer review) is the author/funder, who has granted medRxiv a license to display the preprint in perpetuity.

It is made available under a CC-BY-NC-ND 4.0 International license .

\begin{tabular}{|c|c|}
\hline & $\begin{array}{l}\text { - P18, Black/African/Caribbean/British Black, community service } \\
\text { provider }\end{array}$ \\
\hline $\begin{array}{l}\text { Fear of } \\
\text { implications } \\
\text { from self- } \\
\text { isolation }\end{array}$ & $\begin{array}{l}\text { "My community are poor, most of them are... on benefits,... some of them } \\
\text { are... working... low paid jobs, like cleaners... So...if a person is already } \\
\text { worried if they can put food on the table,... they don't think more about the risk } \\
\text { of what's happening out there... And... there's a lot of... single parents in } \\
\text { Birmingham... What will I do to feed my children if the lockdown happens } \\
\text { and... I lost my job? ... It's very difficult when you're thinking about feeding } \\
\text { your own children and about your health, so you... may go to work... maybe } \\
\text { not feeling well yourself... They were even hiding that they have the COVID-19 } \\
\text { symptoms,... because they cannot afford to stay home." } \\
\text { - P6, Black African/British Black African, radio presenter } \\
\text { "people are not... willing to say, oh l've got symptoms, cuz [because] of fear } \\
\text { that people are not gonna [going to] come near them, but they would talk about } \\
\text { other people, other stories" } \\
\text { - P7, Asian/British Asian, community service provider }\end{array}$ \\
\hline $\begin{array}{l}\text { Reinforced } \\
\text { structural } \\
\text { racism and } \\
\text { prejudice }\end{array}$ & $\begin{array}{l}\text { "The heightened awareness of the fact that it's impacting BME [BAME] } \\
\text { communities has given rise to...justifying hate... and we've seen some of this } \\
\text { manifested online towards our community." } \\
\text { - P1, Asian/British Asian, community service provider } \\
\text { "Our people have lost a lot of family members through this COVID,... People in } \\
\text { our culture, in our community, felt unappreciated, uncared for, lack of value } \\
\text { placed on them, who they are, and what they've accomplished. And even how } \\
\text { they've been treated historically, it's now coming back stronger because } \\
\text { they're now saying... we were asked to come to this country years ago, we } \\
\text { weren't coming here by ourselves,... doing other people's work, come and help } \\
\text { rebuild the country. And now you've done all that, they're treating you as } \\
\text { though you're nothing but a slave, you're just...an intruder in this country." } \\
\text { - P11, Black/African/Caribbean/British Black, church leader }\end{array}$ \\
\hline
\end{tabular}

472 
medRxiv preprint doi: https://doi.org/10.1101/2021.03.03.21252286; this version posted March 3, 2021. The copyright holder for this preprint (which was not certified by peer review) is the author/funder, who has granted medRxiv a license to display the preprint in perpetuity.

It is made available under a CC-BY-NC-ND 4.0 International license .

\section{Table 3 Understanding of risk and disparity in health outcomes for COVID-19}

\begin{tabular}{|c|c|c|}
\hline $\begin{array}{l}\text { Thematic } \\
\text { subtheme }\end{array}$ & $\begin{array}{l}\text { Thematic } \\
\text { Code }\end{array}$ & Illustrative quotes \\
\hline $\begin{array}{l}\text { Acceptance, } \\
\text { scepticism and } \\
\text { ignorance }\end{array}$ & & $\begin{array}{l}\text { "Some of the people that are from back home and they've come } \\
\text { to this country, they have the mentality that, some, not all, some } \\
\text { took it really seriously, but some thought if you were gonna [going } \\
\text { to] get the virus, you were gonna [going to] get it, and they were } \\
\text { quite reluctant to obey the rules." } \\
\text { - P7, Asian/ British Asian, community service provider } \\
\text { "It's a linkage [the disparity], whether it's true or not,... especially } \\
\text { when you then compare it to India, ... whether the numbers are } \\
\text { wrong or not, accurately counted or whatever,... but the margins } \\
\text { cannot be that much. ...It can't be that India... underreport such } \\
\text { less numbers compared to the UK or mainland Europe,... that it } \\
\text { has somehow... not affected Indians ... in India to the same } \\
\text { degree or same level as those in the UK." } \\
\text { - P13, Asian/British Asian, temple manager }\end{array}$ \\
\hline \multirow{6}{*}{$\begin{array}{l}\text { Perceptions } \\
\text { around ethnic, } \\
\text { cultural, societal } \\
\text { and } \\
\text { environmental } \\
\text { contexts as risk } \\
\text { factors }\end{array}$} & $\begin{array}{l}\text { Multi-generational } \\
\text { living }\end{array}$ & $\begin{array}{l}\text { "living with extended people, they said that was a risk of infection } \\
\text { spreading... because the White British public,... they're quite } \\
\text { limited to...their... literal families that they're living with, whereas } \\
\text { we have extended families." } \\
\text { - } \quad \text { P7, Asian/British Asian, community service provider }\end{array}$ \\
\hline & $\begin{array}{l}\text { Education level and } \\
\text { employment }\end{array}$ & $\begin{array}{l}\text { "When you look at... hospitals and health establishments, the } \\
\text { workers there are mainly from the BAME communities, so... they } \\
\text { would be more at risk... because we're the ones... who are on the } \\
\text { front line... to protect people... from COVID." } \\
\text { - P18, Black/African/Caribbean/British Black, community } \\
\text { service provider }\end{array}$ \\
\hline & $\begin{array}{l}\text { Neighbourhood } \\
\text { deprivation or } \\
\text { affluency }\end{array}$ & $\begin{array}{l}\text { "The community... believe that... the Government is not doing } \\
\text { enough in time, and sense that there's a lot of deaths that have } \\
\text { occurred amongst our community,... because they're the poorer } \\
\text { sectors, ... those who live in the... poor housing area" } \\
\text { - P11, Black/African/ Caribbean/ British Black, church } \\
\text { leader }\end{array}$ \\
\hline & $\begin{array}{l}\text { Community } \\
\text { collectivism }\end{array}$ & $\begin{array}{l}\text { "I think for lots of communities..., they see your family, our family } \\
\text { as being one family, almost. So they don't differentiate and think, } \\
\text { well actually, it's households" } \\
\text { - P14, various BAME groups, community service provider }\end{array}$ \\
\hline & $\begin{array}{l}\text { Poor health and } \\
\text { lifestyle and lack of } \\
\text { access to healthy } \\
\text { food }\end{array}$ & $\begin{array}{l}\text { "Our community, the food is not healthy,... they don't eat } \\
\text { balanced diet..., they don't have physical activities. And... they } \\
\text { have different kind of... diseases like diabetic, } \\
\text { heart...problems... and.... cholesterol, and...because of this } \\
\text { they...understand that... we are more vulnerable... compared to } \\
\text { the White community." } \\
\quad \text { - P5, Asian/British Asian, mosque imam }\end{array}$ \\
\hline & Cultural hierarchy & $\begin{array}{l}\text { "We... stay with our grandparents, with our parents...., it's just a } \\
\text { part of our culture.... The teenagers... understand the risk,... but } \\
\text { what can they do? Who's in charge of the house? The } \\
\text { grandparents or the parents are in charge... They may come to } \\
\text { them and say, look, mummy or daddy you cannot go and visit that } \\
\text { person who passed away..., because of COVID-19. They [in } \\
\text { charge] say, oh, you are becoming Western, why you not } \\
\text { understanding... it's our culture? That's our family... Young } \\
\text { people don't have... the authority... The adults cannot } \\
\text { understand... what's the Government saying, what's the Public } \\
\text { Health England saying. So, they don't know, they think ... they're } \\
\text { [young people] exaggerating, they're becoming Western, why are }\end{array}$ \\
\hline
\end{tabular}


medRxiv preprint doi: https://doi.org/10.1101/2021.03.03.21252286; this version posted March 3, 2021. The copyright holder for this preprint (which was not certified by peer review) is the author/funder, who has granted medRxiv a license to display the preprint in perpetuity.

\section{It is made available under a CC-BY-NC-ND 4.0 International license.}

473

they telling us not to go? So... young people understands but... our older ones... don't,... and that's where the risk lies because if they get the infection, young people gets infection because they live together." 
medRxiv preprint doi: https://doi.org/10.1101/2021.03.03.21252286; this version posted March 3, 2021. The copyright holder for this preprint

(which was not certified by peer review) is the author/funder, who has granted medRxiv a license to display the preprint in perpetuity.

It is made available under a CC-BY-NC-ND 4.0 International license .

\section{Table 4 Perception, understanding and adherence to Government guidance in relation to COVID-19}

\begin{tabular}{|c|c|c|}
\hline $\begin{array}{c}\text { Thematic } \\
\text { subtheme }\end{array}$ & $\begin{array}{c}\text { Thematic } \\
\text { Code }\end{array}$ & Illustrative quotes \\
\hline \multirow[t]{2}{*}{$\begin{array}{l}\text { Understanding } \\
\text { and clarity }\end{array}$} & Untimely & $\begin{array}{l}\text { "The Government kept putting out... very much last minute information... } \\
\text { So...for a lot of parents, if they don't access... mainstream news, then where } \\
\text { do they find out information from?" } \\
\text { - P14, various BAME groups, community service provider }\end{array}$ \\
\hline & $\begin{array}{l}\text { Inconsistent, vague } \\
\text { and confusing }\end{array}$ & $\begin{array}{l}\text { "There were lots and lots of mixed messages which... the Government and } \\
\text { local government didn't seize upon quickly enough to try and change that } \\
\text { messaging and adapt so... every community and every family member could } \\
\text { understand it." } \\
\text { - P14, various BAME groups, community service provider }\end{array}$ \\
\hline \multirow[t]{4}{*}{ Poor outreach } & Digital access & $\begin{array}{l}\text { "Some people only had access to computers... if they came to work and they } \\
\text { haven't got computers at home... A lot of the older generation or people on } \\
\text { low incomes, they've got the old-fashioned phones so they can't go on... } \\
\text { things like Facebook and WhatsApp and... other digital platforms... I think } \\
\text { that... the African Caribbean community and... the dual heritage } \\
\text { community,... in terms of digital inclusion, it's a massive issue. And there's a } \\
\text { lot of digital exclusion" } \\
\text { - P19, Black/ African/Caribbean/British Black/White and Black } \\
\text { Caribbean/White and Black African, community service provider }\end{array}$ \\
\hline & $\begin{array}{l}\text { Need for translated } \\
\text { guidance }\end{array}$ & $\begin{array}{l}\text { "Interpreting the guidelines, they needed someone to do that because... } \\
\text { they're not able to read English, they're not able to dissect that information } \\
\text { and process it. So they needed... somebody who's British-born } \\
\text { Bangladeshi... or Pakistani... Indian, to... relay that information to them... } \\
\text { They wouldn't understand the Government guidelines, even when they're } \\
\text { watching the news,... they wouldn't fully understand it" } \\
\text { - P7, Asian/British Asian, community service provider }\end{array}$ \\
\hline & $\begin{array}{l}\text { Need for } \\
\text { cooperation } \\
\text { between } \\
\text { established } \\
\text { community } \\
\text { networks and } \\
\text { Government to } \\
\text { deliver guidance }\end{array}$ & $\begin{array}{l}\text { "The Director of Public Health wants to work with African Caribbean,... dual } \\
\text { heritage and BAME communities... in terms of reinforcing the Hands, Face, } \\
\text { Space message... not to just to protect yourself, to protect your family,... } \\
\text { your friends,... the community as a whole... People like ourselves have to } \\
\text { get involved in that campaign... We're the ones that have gotta [got to] get } \\
\text { that message out there because they're not going to listen to people from } \\
\text { outside... their ethnic group." } \\
\text { - P19, Black/African/Caribbean/British Black/White and Black } \\
\text { Caribbean/White and Black African, community service provider }\end{array}$ \\
\hline & $\begin{array}{l}\text { Cultural sensitivity } \\
\text { and } \\
\text { appropriateness }\end{array}$ & $\begin{array}{l}\text { "It's a double edged sword. On the one hand, the media has been } \\
\text { highlighting the disproportionate impact on the BME [BAME] community. On } \\
\text { the other hand, the way that might have been perceived by some is to say } \\
\text { that...if we have greater interaction with people from BME communities... } \\
\text { then we're more likely to catch it [COVID-19]. And so then as a result,... stay } \\
\text { away" } \\
\text { - P1, Asian/British Asian, community service provider }\end{array}$ \\
\hline \multirow[t]{2}{*}{$\begin{array}{l}\text { Adherence, or } \\
\text { lack of, to } \\
\text { Government } \\
\text { guidance }\end{array}$} & & $\begin{array}{l}\text { "You've got the elderly... who have come to the UK... in the last... } 6 \text { years or } \\
\text { so... they're not really... listening to the restrictions. At the start, none of } \\
\text { them were wearing masks... however with the... younger British teens that } \\
\text { are in the... Pakistani community, they were following the restrictions..., the } \\
\text { guidelines, and they were... more compliant with the rules, rather than the } \\
\text { elderly" } \\
\text { - P9, Asian/British Asian, supermarket manager } \\
\text { "Home remedies are very, very popular within our community,... all the } \\
\text { Sunnahs [practices] of our Prophet peace be upon him... they practice that a } \\
\text { lot...the honey, the dates, the ginger, a lot of people were highly } \\
\text { recommending that... and I think... they take it [Government guidance] very } \\
\text { literally and strictly, so they do follow it... The elderly, they pray at the } \\
\text { mosque, so because that was closed, they were doing it at home" } \\
\text { - P7, Asian/British Asian, community service provider }\end{array}$ \\
\hline & Reinforcement & $\begin{array}{l}\text { "Initially we had half and half, we had people that were serious about it and } \\
\text { we had some people that were not serious about it. So what we did as a } \\
\text { church was to educate them and say..., you need to stay safe and you need } \\
\text { to take care of yourself." } \\
\quad \text { - P15, Black/African/Caribbean/British Black, church staff }\end{array}$ \\
\hline
\end{tabular}


medRxiv preprint doi: https://doi.org/10.1101/2021.03.03.21252286; this version posted March 3, 2021. The copyright holder for this preprint (which was not certified by peer review) is the author/funder, who has granted medRxiv a license to display the preprint in perpetuity.

It is made available under a CC-BY-NC-ND 4.0 International license .

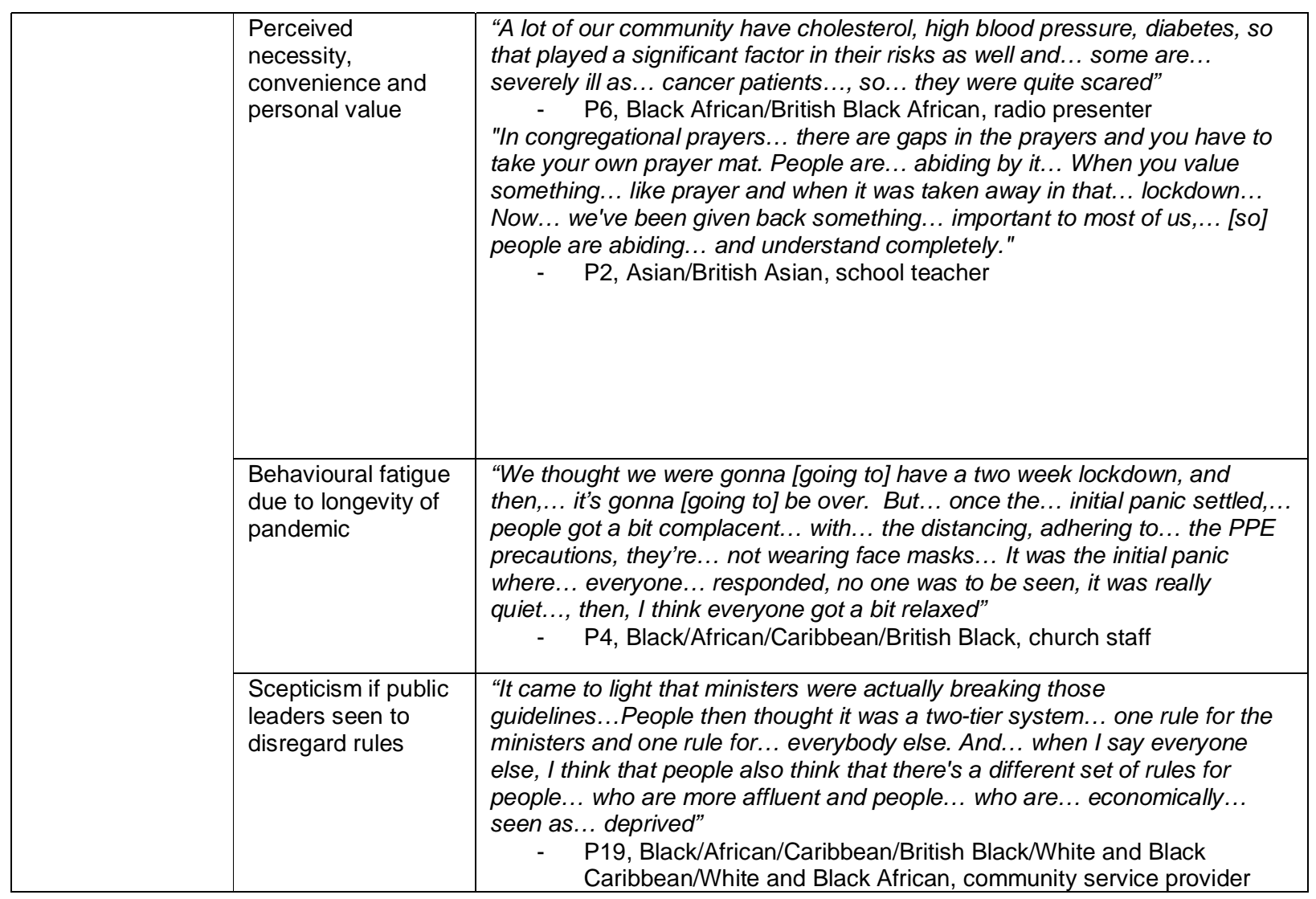


medRxiv preprint doi: https://doi.org/10.1101/2021.03.03.21252286; this version posted March 3, 2021. The copyright holder for this preprint (which was not certified by peer review) is the author/funder, who has granted medRxiv a license to display the preprint in perpetuity.

It is made available under a CC-BY-NC-ND 4.0 International license .

Table 5 Accessibility and use of community services, and other points of support, during the pandemic

\begin{tabular}{|c|c|c|}
\hline $\begin{array}{l}\text { Thematic } \\
\text { subtheme }\end{array}$ & $\begin{array}{l}\text { Thematic } \\
\text { code }\end{array}$ & Illustrative quotes \\
\hline $\begin{array}{l}\text { Accessibility } \\
\text { and lack of } \\
\text { resources }\end{array}$ & & $\begin{array}{l}\text { "The wider community, they need more support. And I would [suggest]... that } \\
\text { every faith group be given resources they need to get the people that are } \\
\text { qualified... If the right resources are put in there, people will find more easy } \\
\text { to... go to temples, the mosque, synagogue and the church and talk to priest, } \\
\text { or a minister, or a qualified counsellor from that group who can deal with them } \\
\text { based on... their faith and know who they are as a community." } \\
\text { - P11, Black/African/Caribbean/British Black, church staff }\end{array}$ \\
\hline \multirow[t]{4}{*}{$\begin{array}{l}\text { Points of } \\
\text { support }\end{array}$} & $\begin{array}{l}\text { Family and } \\
\text { friends }\end{array}$ & $\begin{array}{l}\text { "The people that speak English in the household were responsible for the } \\
\text { shopping, whether it be online or actually attending the actual shops and } \\
\text { getting things" } \\
\text { - P7, Asian/British Asian, community service provider }\end{array}$ \\
\hline & $\begin{array}{l}\text { Places of } \\
\text { worship and } \\
\text { religious } \\
\text { leaders }\end{array}$ & $\begin{array}{l}\text { "The food bank over the past six months has... been inundated with people } \\
\text { from... the community... We started off a drop-off service as well during the } \\
\text { first lockdown... We also have a counselling service as a listening service..., } \\
\text { people, they just, they wanna [want to] talk" } \\
\text { - P10, various BAME groups, mosque imam }\end{array}$ \\
\hline & $\begin{array}{l}\text { Established } \\
\text { community } \\
\text { networks and } \\
\text { centres }\end{array}$ & $\begin{array}{l}\text { "We've got networks..., a lot of community organisations across the borough } \\
\text { that's working together. So we share information and information's gone out in } \\
\text { different languages and... we've got community champions... in the area" } \\
\text { - } \quad \text { P18, Black/African/Caribbean/British Black, community service } \\
\text { provider }\end{array}$ \\
\hline & $\begin{array}{l}\text { Healthcare } \\
\text { professionals }\end{array}$ & $\begin{array}{l}\text { "9 of } 10 \text { people I talk to are having problems to get through to their GPs... The } \\
\text { doctor calls [but they] don't understand what the doctor is saying... Before the } \\
\text { pandemic, people used to take, like, okay, l'll take my friend with me... who } \\
\text { says [English] maybe better than me... But on the phone, they can't... So if } \\
\text { somebody doesn't speak English, or doesn't have... anyone at home... who } \\
\text { can speak English... what will they do?" } \\
\text { - P6, Black African/British Black African, radio presenter }\end{array}$ \\
\hline
\end{tabular}

